\title{
ORIGINALARTICLE
}

\section{The effects of replacement of whole-plant corn with oat and common vetch on the fermentation quality, chemical composition and aerobic stability of total mixed ration silage in Tibet}

\author{
Lei CHEN, ${ }^{1 *}$ Gang GUO, ${ }^{1 *}$ Chengqun $\mathrm{YU}^{2}{ }^{2}$ Jie ZHANG, ${ }^{1}$ Masataka SHIMOJO${ }^{3}$ and Tao SHAO ${ }^{1}$ \\ ${ }^{1}$ Institute of Ensiling and Processing of Grass, College of Animal Science and Technology, Nanjing Agricultural \\ University, Nanjing, ${ }^{2}$ Institute of Geographic Sciences and Natural Resources Research, Chinese Academy of \\ Sciences, Beijing, China; and ${ }^{3}$ Department of Animal and Marine Bioresource Sciences, Faculty of Agriculture, \\ Kyushu University, Fukuoka, Japan
}

\begin{abstract}
The objective of this experiment was to evaluate the effects of replacement of whole-plant corn with oat and common vetch on the fermentation quality, chemical composition and aerobic stability of total mixed ration (TMR) silage in Tibet. Four TMR that varied in the forage sources on dry matter basis were used: (i) 52\% whole-plant corn (Control); (ii) $43 \%$ oat $+12 \%$ common vetch (OC 3.6 ); (iii) $38 \%$ oat $+18 \%$ common vetch (OC2.2); and (iv) $33 \%$ oat $+23 \%$ common vetch (OC 1.5). Silos were opened on day 45 and then subjected to an aerobic stability test for 12 days. The results showed that all silages were well preserved with low $\mathrm{pH}$ and $\mathrm{NH}_{3}-\mathrm{N}$, and high lactic acid and $\mathrm{V}$-scores. With the increasing proportion of common vetch, crude protein, ether extract increased $(P<0.05)$, and neutral detergent fiber and acid detergent fiber decreased $(P<0.05)$. Under aerobic conditions, treated silages were more stable than the control silage as indicated by lower $(P<0.05) \mathrm{pH}$ and yeast population. It was concluded that replacement of whole-plant corn with oat and common vetch had no unfavorable effects on the fermentation quality and improved crude protein content and aerobic stability of TMR silage. OC2.2 silage was the best among three treated TMR silages.
\end{abstract}

Key words: aerobic stability, common vetch, fermentation quality, oat, whole-plant corn.

\section{INTRODUCTION}

The Tibetan plateau located in southwest China with an average altitude of over $4000 \mathrm{~m}$ (Duan et al. 2008), is regarded as the highest unique territorial unit in the world. The development of animal husbandry in Tibet is relatively backward. On the Tibetan Plateau, dairy cows are mainly bred by yak farmers in the pastoral areas and provide $>90 \%$ of milk consumption for the local people. Shortage of feedstuffs is due to seasonal changes throughout the year and yak farmers do not know how to reasonably match roughage and concentrate to feed dairy cows, which results in the fluctuation in production performance of dairy cows. In recent years, total mixed ration (TMR) silage has been widely applied to feeding dairy cows in Tibet, particularly containing whole-plant corn as roughage. TMR silage application can not only facilitate year-round fodder provision and improve nutritive value of forage, but also make up for the inadequacy of feeding roughage and concentrate separately. However, the cultivated areas for whole-plant corn are limited and with low yields, and local whole-plant corn resources cannot meet the needs of the roughage. Thus, wholeplant corn demand is mainly supplied by importing from inland China. This adds an extra cost to feeding.

Oat (Avena sativa) and common vetch (Vicia sativa) are the main cultivated forage in Tibet. Both of them have a long planting history and are suitable for growth in Tibet due to hardy drought-tolerant characteristics. Oat and common vetch contain high crude protein $(\mathrm{CP})$ concentrations. However, common vetch

Correspondence: Tao Shao, Institute of Ensiling and Processing of Grass, College of Animal Science and Technology, Nanjing Agricultural University, Nanjing 210095, China. (Email: taoshaolan@163.com)

*These authors contributed equally to this work. Received 14 July 2013; accepted for publication 3 April 2014. 
is seldom used as material to make silage in Tibet as legumes are often considered hard to ensile well due to low fermentable carbohydrate content in combination with a high buffering capacity (BC) (McDonald et al. 1991; Buxton \& O'Kiely 2003). Because of the chemical composition of whole-crops cereal, mainly in high fermentable carbohydrates, silage of high quality can be made by ensiling mixtures of legumes and cereal crops (Kennelly \& Weinberg 2003). Moreover, a mixture of whole-crop cereals and legume silage is likely to have a higher nutritive value as compared with silage produced from separated crops due to higher CP concentration (Lunnan 1989) and nutrient degradability in the rumen (Mustafa et al. 2000; Salawu et al. 2001), and ruminants tend to eat more of mixed forage than sole forage rations (Huhtanen et al. 2007). Such silages are also suggested to improve rumen microbial yields and supply balanced protein and energy for rumen microbe growth (Adesogan 8 Salawu 2004). Thus, we replaced whole-plant corn with oat and common vetch in combination with a concentrate to make TMR silage. Using this method can solve the problem of roughage restriction and improve nutritive value of forage in Tibet. In previous studies, oat and common vetch were ensiled mainly as single crops (Mustafa et al. 2002; Shao et al. 2005). However, there is no information on effects of replacing of whole-plant corn with oat and common vetch on fermentation quality, aerobic stability and nutritive value of TMR in Tibet.

The objective of this study was to determine effects of replacement of whole-plant corn with oat and common vetch on the fermentation quality, chemical composition and aerobic stability of total mixed ration in Tibet.

\section{MATERIALS AND METHODS Silage preparation}

Whole-plant corn, oat, common vetch were cultivated in the experimental field of the Grassland Station of Rikaze $\left(29.27^{\circ} \mathrm{N}, 88.88^{\circ} \mathrm{E}, 3836 \mathrm{~m}\right.$ a.s.l. Tibet, China); whole-plant corn was harvested at the one-half milk line stage $(227 \mathrm{~g}$
$\mathrm{DM} / \mathrm{kg}$ fresh weight); oat was harvested at the heading stage (318 g DM/kg fresh weight) and common vetch was harvested at the podding stage $(296 \mathrm{~g} \mathrm{DM} / \mathrm{kg}$ fresh weight). Forage was chopped with a conventional forage harvester to lengths of $2-3 \mathrm{~cm}$. The chemical composition of ingredients for TMR is shown in Table 1. The formulation and chemical composition of TMR are shown in Table 2. The control TMR is a regular ration formulation in Tibet, and it contains low $\mathrm{CP}$ content. We aimed to maximize the use of the common vetch, the proportion of common vetch increasing gradually in the treated TMR. The CP was kept at the same level in the treated TMR. Experimental treatments included four TMR that were varied in the forage sources on a DM basis: (i) $52 \%$ whole-plant corn (Control); (ii) $43 \%$ oat $+12 \%$ common vetch (OC3.6; oat: common vetch $=3.6: 1$ ); (iii) $38 \%$ oat + $18 \%$ common vetch (OC2.2; oat: common vetch $=2.2: 1)$; and (iv) $33 \%$ oat $+23 \%$ common vetch (OC1.5; oat: common vetch $=1.5: 1)$. From each treatment of the TMR mixture, samples of $190 \mathrm{~g}$ on a fresh matter base were packed into a laboratory silo (polyethylene bottle, $250 \mathrm{~mL}$ capacity), followed by being sealed with a screw top and plastic tapes, and then kept at ambient temperature. The silos for each treatment were opened at 45 days after ensiling, and then subjected to an aerobic stability test for 12 days. Three replicates per treatment on each sampling day were used for silage quality and aerobic stability analysis.

\section{Chemical and microbiological analyses}

Fresh forage, unensiled TMR and TMR silage were analyzed for chemical and microbiological composition. To measure fermentation indices, $35 \mathrm{~g}$ of each TMR silage was blended with $75 \mathrm{~mL}$ of deionized water extracted at $4^{\circ} \mathrm{C}$ for $24 \mathrm{~h}$. Then, the extracts were filtered through 2 layers of cheesecloth and a filter paper (Xinhua Co., Hangzhou, China). The filtrates were used for determining $\mathrm{pH}, \mathrm{BC}$, ammonia nitrogen $\left(\mathrm{NH}_{3}-\mathrm{N}\right)$, lactic acid and volatile fatty acids (VFAs) concentrations. The $\mathrm{pH}$ of the silage was measured with a glass electrode $\mathrm{pH}$ meter (HANNA pH 211; Hanna Instruments Italia Srl, Villafrance Padovana, Italy). Buffering capacity was determined by the hydrochloric acid-sodium hydroxide method of Playne and McDonald (1966). Ammonia nitrogen was determined using the phenol-hypochlorite reaction method of Broderick and Kang (1980). The lactic acid was determined by the method of Barker and Summerson (1941). Volatile fatty acids were determined with gas chromatography (Shimadzu GC-17A, Kyoto, Japan, with $30 \mathrm{~m} \times 0.25 \mathrm{~mm}$ (film thickness $0.25 \mu \mathrm{m}$ ) capillary column, acid-modified poly (ethylene glycol) phase, GADA-24107,

Table 1 Chemical composition of whole-plant corn, oat, common vetch and mixed concentrate in total mixed ration

\begin{tabular}{lcccc}
\hline & Whole plant corn & Oat & Common vetch & Mixed concentrate+ \\
\hline DM (\%) & 22.7 & 31.8 & 29.6 & 91.6 \\
CP (\% DM) & 5.10 & 11.3 & 19.4 & 22.5 \\
EE (\% DM) & 5.50 & 4.96 & 4.44 & 8.10 \\
aNDFom (\% DM) & 46.7 & 43.5 & 35.7 & 34.2 \\
ADFom (\% DM) & 21.0 & 21.2 & 16.6 & 9.31 \\
Hemicellulose (\% DM) & 25.7 & 22.3 & 19.1 & 24.9 \\
Ash (\% DM) & 4.52 & 6.55 & 7.00 & 9.09 \\
NFC & 38.2 & 33.7 & 33.5 & 26.1 \\
\hline
\end{tabular}

+Mixed concentrate: $7.5 \%$ Crack corn, $20 \%$ rape cake meal, 20\% cotton seed, $27.5 \%$ distillers dried grains with solubles, $20 \%$ wheat bran, 5\% vitamin-mineral. ‡NFC (non-fibrous carbohydrate) = 100-CP-aNDFom-EE-Ash. ADFom, acid detergent fiber; aNDFom, neutral detergent fiber; $\mathrm{CP}$, crude protein; $\mathrm{DM}$, dry matter; $\mathrm{EE}$, ether extract. 
Table 2 Ingredient and chemical composition of total mixed ration

\begin{tabular}{|c|c|c|c|c|c|}
\hline \multirow[t]{2}{*}{ Item } & \multicolumn{4}{|c|}{ Treatments } & \multirow[t]{2}{*}{ SEM } \\
\hline & Control & OC3.6 & OC2.2 & OC1.5 & \\
\hline \multicolumn{6}{|c|}{ Ingredient composition (\% DM) } \\
\hline Whole-crop corn & 52 & & & & \\
\hline Oat & & 43 & 38 & 33 & \\
\hline Common vetch & & 12 & 18 & 23 & \\
\hline Mixed concentrate $†$ & 48 & 45 & 44 & 44 & \\
\hline \multicolumn{6}{|c|}{ Chemical composition (\% DM) } \\
\hline $\mathrm{DM}$ & $35.4 \mathrm{C}$ & $44.6 \mathrm{~A}$ & $43.8 \mathrm{~B}$ & $43.6 \mathrm{~B}$ & 1.17 \\
\hline $\mathrm{CP}$ & $13.8 \mathrm{~B}$ & $17.4 \mathrm{~A}$ & $17.7 \mathrm{~A}$ & $18.1 \mathrm{~A}$ & 0.531 \\
\hline $\mathrm{EE}$ & $6.79 \mathrm{~A}$ & $6.34 \mathrm{~A}$ & $6.26 \mathrm{~A}$ & $6.21 \mathrm{~A}$ & 0.092 \\
\hline aNDFom & $41.1 \mathrm{~A}$ & $38.5 \mathrm{~A}$ & $38.1 \mathrm{~A}$ & $37.4 \mathrm{~A}$ & 0.567 \\
\hline ADFom & $15.6 \mathrm{~A}$ & $15.3 \mathrm{~A}$ & $15.2 \mathrm{~A}$ & $14.8 \mathrm{~A}$ & 0.272 \\
\hline Hemicellulose & $25.6 \mathrm{~A}$ & $23.2 \mathrm{~B}$ & $22.9 \mathrm{~B}$ & $22.6 \mathrm{~B}$ & 0.391 \\
\hline Ash & $6.75 \mathrm{~B}$ & $7.78 \mathrm{~A}$ & 7.77A & $7.75 \mathrm{~A}$ & 0.142 \\
\hline NFC $\ddagger$ & $31.6 \mathrm{~A}$ & $30.0 \mathrm{~A}$ & $30.2 \mathrm{~A}$ & $30.5 \mathrm{~A}$ & 0.415 \\
\hline
\end{tabular}

†Mixed concentrate: $7.5 \%$ Crack corn, 20\% rape cake meal, 20\% cotton seed, $27.5 \%$ distillers dried grains with solubles, $20 \%$ wheat bran, $5 \%$ vitamin-mineral. $\ddagger$ NFC (non-fibrous carbohydrate) $=100-\mathrm{CP}$-aNDFom-EE-Ash. Control $=52 \%$ whole-plant corn and $48 \%$ concentrate, OC $3.6=43 \%$ oat $+12 \%$ common vetch $+45 \%$ concentrate, OC $2.2=38 \%$ oat $+18 \%$ common vetch $+44 \%$ concentrate, $\mathrm{OC} 1.5=33 \%$ oat $+23 \%$ common vetch $+44 \%$ concentrate. Values in the same row (A-D) with different following letters are significantly different $(P<0.05)$. ADFom, acid detergent fiber; aNDFom, neutral detergent fiber; $C P$, cude protein; DM, dry matter; EE, ether extract; SEM, standard error of the mean.

Sigma-Aldrich Co., Kyoto, Japan; condition: column temperature $130^{\circ} \mathrm{C}$, injection temperature $220^{\circ} \mathrm{C}$ ). DM content of unensiled forage samples and TMR silage samples were determined by drying the samples at $60^{\circ} \mathrm{C}$ for $48 \mathrm{~h}$ to a constant mass, which was corrected for loss of volatiles using the equation of Porter and Murray (2001), and then ground to pass through a $2 \mathrm{~mm}$ screen for later analysis. DM recovery of 45 days TMR silages was estimated by comparing the product of forage mass and forage DM contents before and after ensiling for each silo. Crude ash (Ash) was determined by placing samples in a muffle furnace set at $500^{\circ} \mathrm{C}$ for $5 \mathrm{~h}$. The water-soluble carbohydrates (WSC) were determined by colorimetric after-reaction with anthrone reagent (Thomas 1977). The methods of Van Soest et al. (1991) were used for neutral detergent fiber (aNDFom) and acid detergent fiber (ADFom) analysis and the analyses were not sequential. Amylase and sodium sulfite were used in the aNDFom analysis and the results were expressed on a DM basis without residual ash. Hemicellulose $=$ aNDFom - ADFom. Total nitrogen (TN) was analyzed by the Kjeldahl procedure (Krishnamoorthy et al. 1982), CP was determined as the TN multiplied by 6.25. Ether extract (EE) content was determined according to Horii et al. (1971). Non-fibrous carbohydrate (NFC) was calculated by the formula: NFC $=100$ CP-aNDFom-EE-Ash (NRC 2001). To assess the quality of the silage, we calculated the $\mathrm{V}$-score from the $\mathrm{NH}_{3}-\mathrm{N} /$ Total $\mathrm{N}$ and VFA concentrations (Takahashi et al. 2005).

The TMR samples $(10 \mathrm{~g})$ were blended with $90 \mathrm{~mL}$ of sterilized water, and serially diluted in sterilized water. Enumeration of yeasts and lactic acid bacteria (LAB) was done from the fresh TMR and silages (day 45). The number of LAB were measured by plate count on Lactobacilli de Man, Rogosa, Sharpe (MRS) agar incubated at $30^{\circ} \mathrm{C}$ for $48 \mathrm{~h}$ under anaerobic conditions (Anaerobic box; YIHENG Technical co., Ltd, Shanghai, China). Yeasts were counted on potato dextrose agar (Sincere Biotech co., Ltd, Shanghai, China), incubated for $48 \mathrm{~h}$ at $30^{\circ} \mathrm{C}$. Colonies were counted as viable numbers of microorganisms (cfu/g of fresh matter (FM)) from plates containing a minimum of 30 and a maximum of 300 colonies. All the microbiological data were $\log _{10}$ transformed.

\section{Aerobic stability test}

The climate and natural environment are inherently unstable with large differences in temperature between day and night on the Tibetan plateau. The annual average air temperature was $2.38^{\circ} \mathrm{C}$ with extremes of a $25.28^{\circ} \mathrm{C}$ high and a $-32.58^{\circ} \mathrm{C}$ low, and without an absolute frost-free period. During the experiment, the average daytime air temperature was $16.8^{\circ} \mathrm{C}$ and it was $-5.6^{\circ} \mathrm{C}$ at night. We kept the silos in the environmental temperature and it is difficult to control the temperature change. Measuring the temperature change of silages could not properly reflect the aerobic stability. Thus we used the following method to determine aerobic stability of TMR silages. The aerobic stability was defined as the number of hours that the $\mathrm{pH}$ value of the silage remained stable before rising more than 0.5 above the initial $\mathrm{pH}$ value (Zhang \& Kumai 2000; Weinberg et al. 2008). Aerobic stability was measured by placing representatively sampled (disturbed) forage from each silo into plastic bags within an open-top polystyrene box. A total of 48 silos were opened at 45 day and then subjected to aerobic deterioration test for 12 days. During the aerobic exposure stage, triplicate silages of each treatment were sampled on $0,6,9$ and 12 days to determine $\mathrm{pH}$ values, lactic acid content, VFAs and WSC levels, as well as yeast counts. These wet samples were stored at $-20^{\circ} \mathrm{C}$, except for the samples used to determine the microorganisms, which were evaluated immediately.

\section{Statistical analyses}

Analyses were performed using the general linear model procedure (SAS Institute, Cary, NC, USA). Data on chemical and microbiological composition of fresh and ensiled TMR were subjected to one-way analysis of variance (ANOVA). In aerobic conditions, experiments were carried out according 
Table 3 Chemical and microbial composition of four total mixed ration mixtures before being ensiled

\begin{tabular}{|c|c|c|c|c|c|}
\hline \multirow[t]{2}{*}{ Item } & \multicolumn{4}{|c|}{ Treatments } & \multirow[t]{2}{*}{ SEM } \\
\hline & Control & OC3.6 & OC2.2 & OCl.5 & \\
\hline $\mathrm{pH}$ & $5.29 \mathrm{~B}$ & $5.55 \mathrm{~A}$ & $5.54 \mathrm{~A}$ & $5.47 \mathrm{~A}$ & 0.033 \\
\hline WSC (\% DM) & $16.5 \mathrm{~A}$ & $11.2 \mathrm{~B}$ & $11.0 \mathrm{~B}$ & $10.8 \mathrm{~B}$ & 0.742 \\
\hline Buffering capacity (mE/kg DM) & $231 \mathrm{C}$ & $271 \mathrm{~B}$ & $285 \mathrm{AB}$ & 296A & 7.72 \\
\hline Lactic acid bacteria $\left(\log _{10} \mathrm{cfu} / \mathrm{g} F M\right)$ & $5.56 \mathrm{~A}$ & $5.14 \mathrm{~A}$ & $5.52 \mathrm{~A}$ & $5.14 \mathrm{~A}$ & 0.091 \\
\hline Yeast $\left(\log _{10} \mathrm{cfu} / \mathrm{g} F M\right)$ & $4.59 \mathrm{~A}$ & $3.54 \mathrm{BC}$ & $2.96 \mathrm{C}$ & $3.84 \mathrm{AB}$ & 0.189 \\
\hline
\end{tabular}

Control $=52 \%$ whole-plant corn and $48 \%$ concentrate, OC $3.6=43 \%$ oat $+12 \%$ common vetch $+45 \%$ concentrate, OC $2.2=38 \%$ oat $+18 \%$ common vetch $+44 \%$ concentrate, OC $1.5=33 \%$ oat $+23 \%$ common vetch $+44 \%$ concentrate. Values in the same row (A-D) with different following letters are significantly different $(P<0.05)$.

DM, dry matter; FM, fresh matter; SEM, standard error of the mean; WSC, water soluble carbohydrate.

Table 4 Chemical and microbial composition of total mixed ration silages after 45 days of ensiling

\begin{tabular}{|c|c|c|c|c|c|}
\hline \multirow[t]{2}{*}{ Item } & \multicolumn{4}{|c|}{ Treatments } & \multirow[t]{2}{*}{ SEM } \\
\hline & Control & OC3.6 & OC2.2 & OC 1.5 & \\
\hline DM recovery (g/kg, FM) & $91.7 \mathrm{~B}$ & $97.5 \mathrm{~A}$ & 97.7A & $97.5 \mathrm{~A}$ & 0.772 \\
\hline $\mathrm{pH}$ & $3.90 \mathrm{~B}$ & $4.22 \mathrm{~A}$ & $4.19 \mathrm{~A}$ & $4.14 \mathrm{~A}$ & 0.004 \\
\hline Lactic acid (\% DM) & $8.65 \mathrm{~A}$ & $6.81 \mathrm{~B}$ & $6.21 \mathrm{~B}$ & $6.79 \mathrm{~B}$ & 0.285 \\
\hline Acetic acid (\% DM) & $1.22 \mathrm{~A}$ & $1.07 \mathrm{AB}$ & $1.04 \mathrm{AB}$ & $0.826 \mathrm{~B}$ & 0.050 \\
\hline Lactic acid / Acetic acid & $7.10 \mathrm{AB}$ & $6.53 \mathrm{~B}$ & $5.99 \mathrm{~B}$ & $8.25 \mathrm{~A}$ & 0.029 \\
\hline Propionic acid (\% DM) & 0.017 & 0.014 & 0.021 & 0.027 & 0.002 \\
\hline Butyric acid (\% DM) & 0.019 & ND & ND & ND & \\
\hline VFAs (\% DM) & $1.26 \mathrm{~A}$ & $1.08 \mathrm{~B}$ & $1.06 \mathrm{~B}$ & $0.852 \mathrm{C}$ & 0.044 \\
\hline WSC (\% DM) & $3.99 \mathrm{C}$ & $5.39 \mathrm{~B}$ & $5.94 \mathrm{~A}$ & $5.55 \mathrm{~B}$ & 0.224 \\
\hline $\mathrm{NH}_{3}-\mathrm{N}(\% \mathrm{TN})$ & $5.28 \mathrm{AB}$ & $5.53 \mathrm{~A}$ & $5.17 \mathrm{AB}$ & $4.79 \mathrm{~B}$ & 0.100 \\
\hline Lactic acid bacteria $\left(\log _{10} \mathrm{cfu} / \mathrm{g} F M\right)$ & $6.30 \mathrm{~A}$ & $6.74 \mathrm{~A}$ & $6.71 \mathrm{~A}$ & $6.72 \mathrm{~A}$ & 0.014 \\
\hline Yeast $\left(\log _{10} \mathrm{cfu} / \mathrm{g} \mathrm{FM}\right)$ & $<2.00$ & $<2.00$ & $<2.00$ & $<2.00$ & \\
\hline V-score & 97 & 96 & 97 & 98 & 0.023 \\
\hline
\end{tabular}

Control $=52 \%$ whole-plant corn and $48 \%$ concentrate, OC $3.6=43 \%$ oat $+12 \%$ common vetch $+45 \%$ concentrate, OC $2.2=38 \%$ oat + $18 \%$ common vetch $+44 \%$ concentrate, OC $1.5=33 \%$ oat $+23 \%$ common vetch $+44 \%$ concentrate. Values in the same row (A-D) with different following letters are significantly different $(P<0.05)$. DM, dry matter; ND, not detected; SEM, standard error of the mean; VFAs, volatile fatty acids; WSC, water soluble carbohydrate.

to completely randomized factorial design with TMR and deterioration period as two factors. The data were subjected to two-way analysis of variance. Statistical difference between means was determined by Tukey's multiple comparison. Differences were considered significant when probability was less than 0.05 .

\section{RESULTS}

\section{Chemical composition of materials and TMR before ensiling}

As shown in Table 1, the contents of DM and CP of the whole-plant corn were less than those in the oat, common vetch and mixed concentrate. Levels of DM, $\mathrm{CP}, \mathrm{EE}$ were highest in the mixed concentrate. Among the four materials, aNDFom and NFC were highest in the whole-plant corn.

In TMR before ensiling, no notable differences occurred in EE, aNDFom and ADFom, but DM, Ash and $\mathrm{CP}$ increased $(P<0.05)$, and hemicellulose $(P<0.05)$ decreased by replacement of whole-plant corn with oats and common vetch (Table 2). The $\mathrm{pH}$ and $\mathrm{BC}$ for the three treated TMR were higher $(P<0.05)$ than that for the control TMR and OC1.5
TMR had the highest $(P<0.05)$ BC. The WSC contents of the three treated TMR were lower $(P<0.05)$ than that of the control (Table 3). The LAB populations were not different among the four TMR, while the control TMR had higher $(P<0.05)$ yeast population than OC3.6 and OC 2.2 TMR.

\section{Fermentation quality and aerobic stability}

The four silages were well preserved, as indicated by low $\mathrm{pH}$ values and $\mathrm{NH}_{3}-\mathrm{N} / \mathrm{TN}$ ratio, high lactic acid contents as well as V-scores (Table 4). Although levels of propionic acid and $\mathrm{V}$-scores did not differ, $\mathrm{pH}$ values, lactic acid contents, acetic acid contents, WSC contents and $\mathrm{NH}_{3}-\mathrm{N} / \mathrm{TN}$ ratio did $(P<0.05)$, with $\mathrm{pH}$ values ranging from 3.90 to 4.22 . The lactic acid contents of the three treated silages were lower $(P<0.05)$ than that of control silage. The acetic acid content for the OC1.5 silage in particular was lower $(P<0.05)$ than that for the control silage. Lactic acid /acetic acid ratio was significantly higher in OC1.5 silage than that in OC3.6 and OC2.2 silages. Total VFA contents were lower in treated silages than that in the control silage 
Table 5 Chemical composition of four total mixed ration silages after 45 days of ensiling

\begin{tabular}{|c|c|c|c|c|c|}
\hline \multirow[t]{2}{*}{ Item } & \multicolumn{4}{|c|}{ Treatments } & \multirow[t]{2}{*}{ SEM } \\
\hline & Control & OC3.6 & OC2.2 & OC 1.5 & \\
\hline $\mathrm{DM}(\%)$ & $32.7 \mathrm{C}$ & $43.8 \mathrm{~A}$ & 42.9B & $43.0 \mathrm{~B}$ & 1.39 \\
\hline $\mathrm{CP}(\% \mathrm{DM})$ & $14.2 \mathrm{C}$ & $18.0 \mathrm{~B}$ & $19.4 \mathrm{~A}$ & $19.0 \mathrm{~A}$ & 0.631 \\
\hline EE (\% DM) & $7.71 \mathrm{~B}$ & 7.77B & $8.78 \mathrm{~A}$ & $9.16 \mathrm{~A}$ & 0.202 \\
\hline aNDFom (\% DM) & $39.5 \mathrm{~A}$ & $31.5 \mathrm{~B}$ & $30.3 \mathrm{~B}$ & $30.3 \mathrm{~B}$ & 1.24 \\
\hline ADFom (\% DM) & $15.2 \mathrm{~A}$ & $13.6 \mathrm{AB}$ & $13.0 \mathrm{~B}$ & $13.5 \mathrm{AB}$ & 0.319 \\
\hline Hemicellulose (\% DM) & $24.3 \mathrm{~A}$ & $18.0 \mathrm{~B}$ & $17.4 \mathrm{~B}$ & 16.7B & 1.08 \\
\hline Ash (\% DM) & $8.06 \mathrm{~A}$ & $8.07 \mathrm{~A}$ & $8.14 \mathrm{~A}$ & $8.13 \mathrm{~A}$ & 0.032 \\
\hline NFC ( \% DM) & $30.5 \mathrm{~A}$ & $33.7 \mathrm{~A}$ & $33.4 \mathrm{~A}$ & $34.5 \mathrm{~A}$ & 0.628 \\
\hline
\end{tabular}

NFC (non-fibrous carbohydrate) $=100-C P$-aNDFom-EE-Ash; Control $=52 \%$ whole-plant corn and $48 \%$ concentrate, OC $3.6=43 \%$ oat + $12 \%$ common vetch $+45 \%$ concentrate, OC $2.2=38 \%$ oat $+18 \%$ common vetch $+44 \%$ concentrate, OC $1.5=33 \%$ oat $+23 \%$ common vetch $+44 \%$ concentrate. Values in the same row (A-D) with different following letters are significantly different $(P<0.05)$. ADFom, acid detergent fiber; aNDFom, neutral detergent fiber; CP, crude protein; DM, dry matter; EE, ether extract; SEM, standard error of the mean.

Table 6 Chemical and microbial composition of four total mixed ration silages after exposure to air

\begin{tabular}{|c|c|c|c|c|c|c|c|c|c|c|}
\hline \multirow[t]{2}{*}{ Item } & \multirow[t]{2}{*}{ Treatments } & \multicolumn{4}{|c|}{ Days after unloading } & \multirow[t]{2}{*}{ Mean } & \multicolumn{3}{|c|}{ Analysis of variance } & \multirow[t]{2}{*}{ SEM } \\
\hline & & 0 & 6 & 9 & 12 & & $\mathrm{~T}$ & $\mathrm{D}$ & $\mathrm{T} \times \mathrm{D}$ & \\
\hline \multirow[t]{4}{*}{$\mathrm{pH}$} & Control & $3.90 \mathrm{D}$ & $4.28 \mathrm{C}$ & $5.10 \mathrm{~B}$ & $7.07 \mathrm{~A}$ & $5.09 a$ & ** & ** & $* *$ & 0.37 \\
\hline & OC3.6 & $4.22 \mathrm{~A}$ & $4.19 \mathrm{~A}$ & $4.24 \mathrm{~A}$ & $4.23 \mathrm{~A}$ & $4.22 c$ & & & & 0.009 \\
\hline & OC2.2 & $4.19 \mathrm{~A}$ & $4.24 \mathrm{~A}$ & $4.21 \mathrm{~A}$ & $4.18 \mathrm{~A}$ & $4.21 \mathrm{c}$ & & & & 0.009 \\
\hline & OC 1.5 & $4.14 \mathrm{~B}$ & $4.32 \mathrm{~B}$ & $4.34 \mathrm{~B}$ & $4.77 \mathrm{~A}$ & $4.39 b$ & & & & 0.072 \\
\hline \multirow[t]{4}{*}{ Lactic acid (\%DM) } & Control & $8.65 \mathrm{~A}$ & $6.70 \mathrm{~B}$ & $3.86 \mathrm{C}$ & $1.55 \mathrm{D}$ & $5.19 \mathrm{c}$ & $* *$ & $* *$ & $* *$ & 0.818 \\
\hline & OC3.6 & $6.81 \mathrm{~A}$ & $6.61 \mathrm{~A}$ & $5.59 \mathrm{AB}$ & $5.09 \mathrm{~B}$ & $6.02 a$ & & & & 0.241 \\
\hline & OC2.2 & $6.21 \mathrm{~A}$ & $5.91 \mathrm{~A}$ & $5.66 \mathrm{~A}$ & $5.41 \mathrm{~A}$ & $5.80 \mathrm{ab}$ & & & & 0.197 \\
\hline & OC 1.5 & $6.79 \mathrm{~A}$ & $5.68 \mathrm{~B}$ & $5.60 \mathrm{~B}$ & $3.83 \mathrm{C}$ & $5.48 \mathrm{bc}$ & & & & 0.337 \\
\hline \multirow[t]{4}{*}{ WSC (\% DM) } & Control & $4.00 \mathrm{~A}$ & $3.46 \mathrm{AB}$ & $2.92 \mathrm{~B}$ & $2.96 \mathrm{~B}$ & $3.33 c$ & $* *$ & $* *$ & $* *$ & 0.138 \\
\hline & OC3.6 & $5.41 \mathrm{~A}$ & $4.67 \mathrm{~B}$ & $3.98 \mathrm{~B}$ & $3.15 \mathrm{C}$ & $4.30 \mathrm{~b}$ & & & & 0.262 \\
\hline & OC2.2 & $5.94 \mathrm{~A}$ & $5.28 \mathrm{~A}$ & $4.48 \mathrm{~B}$ & $3.68 \mathrm{C}$ & $4.85 a$ & & & & 0.266 \\
\hline & OC 1.5 & $5.58 \mathrm{~A}$ & $4.44 \mathrm{~B}$ & $4.15 \mathrm{~B}$ & $2.73 \mathrm{C}$ & $4.23 \mathrm{~b}$ & & & & 0.310 \\
\hline \multirow[t]{4}{*}{ VFAs (\% DM) } & Control & $1.26 \mathrm{~A}$ & $0.472 \mathrm{~B}$ & $0.290 \mathrm{~B}$ & $0.326 \mathrm{~B}$ & $0.586 c$ & $* *$ & $* *$ & $* *$ & 0.119 \\
\hline & OC3.6 & $1.09 \mathrm{~A}$ & $1.16 \mathrm{~A}$ & $0.880 \mathrm{~B}$ & 0.977A & $1.03 a$ & & & & 0.040 \\
\hline & OC2.2 & $1.06 \mathrm{~A}$ & $0.956 \mathrm{~A}$ & $0.735 \mathrm{~B}$ & $0.964 \mathrm{~A}$ & $0.929 b$ & & & & 0.040 \\
\hline & OC 1.5 & $0.855 \mathrm{~A}$ & $0.358 \mathrm{~B}$ & $0.225 \mathrm{~B}$ & $0.199 \mathrm{~B}$ & $0.409 \mathrm{~d}$ & & & & 0.080 \\
\hline \multirow[t]{4}{*}{ Yeasts $\left(\log _{10} \mathrm{cfu} / \mathrm{g} \mathrm{FM}\right)$} & Control & $2.00 \mathrm{~B}$ & $8.46 \mathrm{~A}$ & $8.75 \mathrm{~A}$ & $8.58 \mathrm{~A}$ & $6.95 a$ & $* *$ & ** & $* *$ & 0.861 \\
\hline & OC3.6 & $2.00 \mathrm{C}$ & $4.60 \mathrm{~B}$ & $4.60 \mathrm{~B}$ & $6.60 \mathrm{~A}$ & $4.45 c$ & & & & 0.488 \\
\hline & OC2.2 & $2.00 \mathrm{C}$ & $3.53 \mathrm{~B}$ & $4.27 \mathrm{~A}$ & $4.60 \mathrm{~A}$ & $3.60 \mathrm{~d}$ & & & & 0.311 \\
\hline & OC 1.5 & $2.00 \mathrm{C}$ & $6.12 \mathrm{~B}$ & $6.42 \mathrm{~B}$ & $7.54 \mathrm{~A}$ & $5.52 \mathrm{~b}$ & & & & 0.638 \\
\hline
\end{tabular}

$* * P<0.01$. Control $=52 \%$ whole-plant corn and $48 \%$ concentrate, OC $3.6=43 \%$ oat $+12 \%$ common vetch $+45 \%$ concentrate, OC2. $2=38 \%$ oat $+18 \%$ common vetch $+44 \%$ concentrate, OC $1.5=33 \%$ oat $+23 \%$ common vetch $+44 \%$ concentrate. Values in the same row (A-D) or in the same column $(\mathrm{a}-\mathrm{d})$ with different following letters are significantly different $(P<0.05)$. D, effect of deterioration period; DM, dry matter; SEM, standard error of the mean; T, effect of treatment; VFAs, volatile fatty acids; WSC, water soluble carbohydrate.

and lowest in OC1.5 silage. The WSC contents of the three treated silages were higher $(P<0.05)$ than that of the control silage and highest in OC2.2 silage. $\mathrm{NH}_{3}-$ N/TN ratio was lowest in the OC1.5 silage. Butyric acids were found in trace quantities in treated silages.

After ensiling for 45 days, Ash in the control silage and treated silages were not notably different, but DM, $\mathrm{CP}$, EE increased $(P<0.05)$ with addition of oats and common vetch (Table 5). The aNDFom, aADFom and hemicellulose decreased $(P<0.05)$ with addition of oats and common vetch. In addition, DM for OC3.6 silage were higher $(P<0.05)$ than that for OC2.2 and OC1.5 silages, while CP, EE for OC3.6 silage were lower $(P<0.05)$ than that for either OC2.2 or OC 1.5 silages.
Yeast numbers were $>10^{7} \mathrm{cfu} / \mathrm{g}$ after aerobic exposure for 12 days in the control and OC1.5 silages (Table 6). While yeast numbers were still $<10^{5} \mathrm{cfu} / \mathrm{g}$ in OC2.2 silages, and $<10^{7} \mathrm{cfu} / \mathrm{g}$ in OC3.6 silage. The lactic acid contents started to decrease gradually at the beginning of the deterioration test and reached the lowest value at 12 days in the control and OC1.5 silages. The lactic acid content began to decrease significantly in OC3.6 silage at 12 days. The $\mathrm{pH}$ in the control and OC1.5 silages were raised from 3.90 to 7.07 and 4.14 to 4.77 , respectively. The $\mathrm{pH}$ in OC2.2 and OC3.6 silages were unchanged, particularly the $\mathrm{pH}$ in OC2.2 silage maintained as low as 4.20 until aerobic exposure was terminated after 12 days. The VFA contents decreased gradually in the control and 
OC1.5 silages, while the VFAs contents in OC3.6 and OC2.2 silages did not change significantly. The WSC contents decreased gradually in all silages with time of aerobic exposure. After aerobic exposure (day 12), OC1.5 silage had the lowest WSC content and OC 2.2 silage had the highest WSC content.

\section{DISCUSSION}

The rate and extent of the resulting fermentation was influenced strongly by the DM content of a crop, a clostridial fermentation and subsequent poor acceptance of the silage by the animals might result from a low DM content with a low sugar content at ensiling (Fraser et al. 2000). In the present study, fermentation quality of the control silage and treated silages were affected by the difference in DM content between control TMR and treated TMR. High DM content delays bacterial multiplication in grass silage. The effect of decreasing the moisture content on the activity of LAB and other microorganisms was reflected in the high residual amounts of soluble carbohydrate in treated silage. Other fermentation products, especially acetic and butyric acids were also relatively low in treated silage. This is consistent with the findings of Morgan etal. (1980). Although fermentation in treated silages was restricted as compared with that in the control silage, four TMR before ensiling contained high WSC content, proper DM content and LAB populations were more than $10^{5} \mathrm{cfu} / \mathrm{g} \mathrm{FM}$, which is critical for a successful fermentation (Weinberg 2008). After ensling for 45 days, the $\mathrm{pH}$ of the four TMR silages reduced to 4.2 or less, which was characteristic of well-preserved silages (Weinberg 2008). Ammonia nitrogen content is related to $\mathrm{CP}$ degradation in all silages, which reveals the extent of proteolysis in silage (Wilkinson 2005) and well-preserved silages should have less than $100 \mathrm{~g} \mathrm{NH}_{3}-\mathrm{N} / \mathrm{kg} \mathrm{TN}$ (McDonald et al. 2002). The $\mathrm{NH}_{3}-\mathrm{N}$ contents of four TMR silages were less than $56 \mathrm{~g} \mathrm{NH}_{3}-\mathrm{N} / \mathrm{kg} \mathrm{TN}$ in the present study which was an indicator of well-preserved silages. The control TMR silage had lower $\mathrm{pH}$ value and higher lactic acid content than the treated TMR silages, which might be attributed to the control TMR having higher WSC content and lower BC than the treated TMR. Higher WSC content could provide more substrates for LAB fermentation, thus stimulating fermentation; lower $\mathrm{BC}$ of the control TMR silage made it less resistant to change in $\mathrm{pH}$, which affected the final content decreasing in $\mathrm{pH}$. In the present study, the acetic acid and total VFAs contents of treated silages decreased with increasing proportion of common vetch, which was inconsistent with the result reported by Pursiainen and Tuori (2008). They found acetic acid and total VFA contents increased with increasing the proportion of common vetch in the mixed silage of common vetch and wheat herbage. Moreover, the $\mathrm{NH}_{3}-\mathrm{N}$ content also decreased gradually with increasing proportion of common vetch in treated silages, suggesting that legumes might have some chemical or biological effects on bacterial flora during ensiling. This might be attributed to treated silages being successful in partially made LAB dominating the microflora and enhancing metabolism to a more homofermentative process as indicated by high lactic acid content, lactic acid/acetic acid ratio and low $\mathrm{NH}_{3}-\mathrm{N}$ content throughout the whole fermented period. However, the mechanism underlying this phenomenon is not clear. It needs further research.

Crude ash content increased a little throughout the experiment, which might be attributed to DM loss. Garcia et al. (1989) reported that the increase in ash content as percentage of DM indicates DM loss. The CP of the four TMR silages also increased, which might be attributed to efficient fermentation, preservation and stability of silages; different types of bacteria presenting in the medium could not perform their activity and they became the part of the medium (silages). These bacteria contain amounts of protein which are part of the structure of bacteria. This result is consistent with that of Bilal (2009). There were differences in aNDFom in the unensiled treated TMR compared with values of treated silages. The aNDFom and hemicellulose of the treated silages were much lower than the unensiled TMR. In contrast, the ADFom of the treated silages was similar to the unensiled treated TMR. Apparently, considerable loss of hemicellulose occurred in the ensiling process. This loss could be due to a combination of enzymatic and acid hydrolysis of the more digestible cell wall fractions during the fermentation which was consistent with results of Basso et al. (2012). Adding oat and common vetch had no unfavorable effect on the fermentation quality of TMR silage as indicated by high lactic acid content and low $\mathrm{pH}$. In addition, the feeding value including $\mathrm{CP}$ and EE contents improved with the increasing proportion of common vetch in TMR silage in Tibet. OC2.2 and OC1.5 silages have better feeding value and fermentation quality than OC3.6 silage.

When exposed to air for 12 days (Table 6), according to the evidence that silages of greater levels of lactic acid or those with more residual sugar contents were less stable when exposed to air (Weinberg $\&$ Muck 1996), it was anticipated that the TMR silages would rapidly deteriorate. The same result was observed in the control silage. The $\mathrm{pH}$ of the control silage increased gradually with the time of aerobic exposure which might be attributed to decreasing lactic acid. The $\mathrm{pH}$ was an indicator of aerobic deterioration of the silage because the lactic acid was consumed by yeasts during aerobic exposure, and then the silage becomes suitable for the growth of other undesirable microorganisms such as molds and aerobic bacteria (Basso et al. 2012). Hara and Ohyama (1978) also reported 
that if silage deteriorated, the content of lactic acid would be lowered and the $\mathrm{pH}$ raised. At 9 days, the $\mathrm{pH}$ in the control silage had already risen to 5.1, thus we deemed it as aerobic deterioration because it was more than 0.5 above the initial $\mathrm{pH}$ value (3.9). Similar with the control silage, the lactic acid content decreased gradually in OC1.5 silage and reached the lowest value at the end of the aerobic stability test, it was considered that OC 1.5 silage had aerobic deterioration at about 12 days. However, the opposite result was observed in OC3.6 and OC2.2 silages. The $\mathrm{pH}$ value of OC3.6 and OC2.2 silages did not change throughout the whole stage of aerobic exposure. This might be explained by the fact that OC3.6 and OC2.2 silages had higher aerobic stability than the control and OC1.5 silages. The lactic acid content decreased a little in OC3.6 and OC2.2 silages with time of aerobic exposure. Therefore, the deceased contents of lactic acid in OC3.6 and OC2.2 silages were not enough to change the $\mathrm{pH}$ in our study. It was difficult to explain the result that treated silages prolonged the hours of aerobic stability but low numbers of yeasts in silages might be associated with enhanced stability (Nishino et al. 2003). Yeasts have long been considered to be responsible for the aerobic deterioration of silage and silages containing at least $1 \times 10^{5} \mathrm{cfu}$ of yeasts/g are prone to undergo aerobic deterioration once exposed to air (Mcdonald et al. 1991). Our results confirmed lower yeast numbers in OC3.6 and OC 2.2 silages as compared with that in the control and OC 1.5 silages after aerobic exposure for 6, 9 and 12 days. Another explanation for aerobic stability enhancing effect of treated silages might be attributed to better aerobic stability of legume silages. It is suggested to be the consequence of inherent factors (e.g. saponins) which are inhibitory to fungi (Weinberg et al. 1999; Adesogan \& Salawu 2004). Yeast numbers were higher in OCl.5 silage than that in OC3.6 and OC2.2 silages, which might be attributed to the decreasing content of VFAs during aerobic exposure stage. Moon (1983) reported volatile fatty acids protected the silage against aerobic yeasts and molds. The result of aerobic stability test showed that OC2.2 silage is the best regarding aerobic stability as indicated by higher lactic acid content, lower $\mathrm{pH}$ and yeast numbers than other silages.

\section{Conclusions}

According to the results of our study, it was concluded that replacement of whole-plant corn with oats and common vetch had no unfavorable effect on fermentation quality, while improving CP content and aerobic stability of TMR silage in Tibet. We suggest that oats and common vetch can be potential sources of roughage of TMR silage in Tibet and OC2.2 TMR silage was the best among the three treated TMR silages. However, further research is needed to better determine the methods for practical production and application.

\section{ACKNOWLEDGMENTS}

This work was supported by the key techniques research in total mixed ration silage from Tibet and the grant of National '12th Five-Year' Plan for Science and Technology Support project: Comprehensive treatment key technology and demonstration project of the Degraded grassland in north Tibetan Plateau (2011BAC09B03) and Tibet innovation platform construction by Chinese Academy of Sciences construction and demonstration of agriculture and animal husbandry combination technology to promote the income of farmers and herdsmen in Tibet.

\section{REFERENCES}

Adesogan AT, Salawu MB. 2004. Effect of applying formic acid, heterolactic bacteria or homolactic and heterolactic bacteria on the fermentation of bi-crops of peas and wheat. Journal of the Science of Food and Agriculture 84, 983-992.

Barker SB, Summerson WH. 1941. The colorimetric determination of lactic acid in biological material. Journal of Biological Chemistry 138, 535-554.

Basso FC, Bernardes TF, Roth APDTP, Lodo BN, Berchielli TT, Reis RA. 2012. Fermentation and aerobic stability of corn silage inoculated with Lactobacillus buchneri. Revista Brasileira de Zootecnia 41, 1789-1794.

Bilal MQ. 2009. Effect of molasses and corn as silage additives on the characteristics of mott dwarf elephant grass silage at different fermentation periods. Parameters 45, 19-23.

Broderick GA, Kang JH. 1980. Automated simultaneous determination of ammonia and total amino acids in ruminal fluid and in vitro media. Journal of Dairy Science 63, 64-75.

Buxton DR, O'Kiely P. 2003. Preharvest plant factors affecting ensiling. Agronomy 42, 199-250.

Duan YH, Tan ZF, Wang YP, Li ZW, Li ZY, Qin GY, et al. 2008. Identification and Characterization of lactic acid bacteria isolated from Tibetan Qula cheese. Journal of General and Applied Microbiology 54, 51-60.

Fraser MD, Fychan R, Jones R. 2000. Voluntary intake, digestibility and nitrogen utilization by sheep fed ensiled forage legumes. Grass and Forage Science 55, 271279.

Garcia AD, Olson WG, Otterby DE, Linn JG, Hansen WP. 1989. Effects of temperature, moisture, and aeration on fermentation of alfalfa silage. Journal of Dairy Science 72, 93-103.

Hara S, Ohyama Y. 1978. Propionic acid application in preventing aerobic deterioration of silage, with references to the relationship to moisture content and additive tolerant microorganisms. Japanese Journal of Zootechnical Science 49, 794-801.

Horii S, Kurata Y, Hayashi Y, Tanabe S. 1971. Physicochemical analytical method for nutritional experiments. In: Morimoto H (ed.), Animal Nutrition Testing Method, lst edn. pp. 280-298. Yokendo, Tokyo. 
Huhtanen P, Rinne M, Nousiainen J. 2007. Evaluation of the factors affecting silage intake of dairy cows: a revision of the relative silage dry-matter intake index. Anima 1, 758770 .

Kennelly JJ, Weinberg ZG. 2003. Small grain silage. In: Buxton DR, Muck RE, Harrison JH (eds), Silage Science and Technology, pp. 749-779. ASA-CSSA-SSSA, Madison, WI, USA.

Krishnamoorthy U, Muscato TV, Sniffen CJ, Van Soest PJ. 1982. Nitrogen fractions in selected feedstuffs. Journal of Dairy Science 65, 217-225.

Lunnan T. 1989. Barley-pea mixtures for whole crop forage. Effects of different cultural practices on yield and quality. Norwegian Journal of Agricultural Sciences 3, 57-71.

McDonald P, Edwards RA, Greenhalgh JFD, Morgan CA. 2002. Animal Nutrition, 6th edn. Longman Scientific and Technical, Harlow, UK.

McDonald P, Henderson AR, Heron SJE. 1991. Microorganisms. In: McDonald P, Henderson AR, Heron SJE (eds), The Biochemistry of Silage, pp. 81-151. Chalombe Publications, Marlow.

Moon NJ. 1983. Inhibition of the growth of acid tolerant yeasts by acetate, lactate and propionate and their synergistic mixtures. Journal of Applied Microbiology 55, 453460.

Morgan CA, Edwards RA, McDonald P. 1980. Intake and metabolism studies with fresh and wilted silages. The Journal of Agricultural Science 94, 287-298.

Mustafa AF, Christensen DA, McKinnon JJ. 2000. Effects of pea, barley, and alfalfa silage on ruminal nutrient degradability and performance of dairy cows. Journal of Dairy Science 83, 2859-2865.

Mustafa AF, Seguin P, Ouellet DR, Adelye I. 2002. Effects of cultivars on ensiling characteristics, chemical composition, and ruminal degradability of pea silage. Journal of Dairy Science 85, 341 1-3419.

Nishino N, Yoshida M, Shiota H, Sakaguchi E. 2003. Accumulation of 1, 2-propanediol and enhancement of aerobic stability in whole crop maize silage inoculated with Lactobacillus buchneri. Journal of Applied Microbiology 94, 800-807.

NRC. 2001. Nutrient Requirements of Dairy Cattle, 7th rev. edn. National Academy Press, Washington, DC.

Playne MJ, McDonald P. 1966. The buffering constituents of herbage and silage. Journal of Science Food and Agriculture 17, 264-266.

Porter MG, Murray RS. 2001. The volatility of components of grass silage on oven drying and the inter-relationship between dry-matter content estimated by different analytical methods. Grass and Forage Science 56, 405-411.

Pursiainen P, Tuori M. 2008. Effect of ensiling field bean, field pea and common vetch in different proportions with whole-crop wheat using formic acid or an inoculant on fermentation characteristics. Grass and Forage Science 63, 60-78.

Salawu MB, Warren EH, Adesogan AT. 2001. Fermentation characteristics, aerobic stability and ruminal degradation of ensiled pea/wheat bi-crop forages treated with two microbial inoculants, formic acid or quebracho tannins. Journal of the Science of the Food and Agriculture 81, 12631268.

Shao T, Shimojo M, Wang T, Masuda Y. 2005. Effect of additives on the fermentation quality and residual monoand di-saccharides compositions of Forage Oats (Avena sativa L.) and Italian Ryegrass (Lolium multiflorum Lam.) silages. Asian Australasian Journal of Animal Sciences 18, 1582-1588.

Takahashi T, Horiguchi K, Goto M. 2005. Effect of crushing unhulled rice and the addition of fermented juice of epiphytic lactic acid bacteria on the fermentation quality of whole crop rice silage, and its digestibility and rumen fermentation status in sheep. Animal Science Journal 76, 353-358.

Thomas TA. 1977. An automated procedure for the determination of soluble carbohydrates in herbage. Journal of Science of the Food and Agriculture 28, 639-642.

Van Soest PJ, Robertson JB, Lewis BA. 1991. Methods for dietary fiber, neutral detergent fiber, and non-starch polysaccharides in relation to animal nutrition. Journal of Dairy Science 74, 3583-3597.

Weinberg ZG. 2008. Preservation of forage crops by solidstate lactic acid fermentation-ensiling. In: Weinberg ZG (ed.), Current Developments in Solid-State Fermentation, pp. 443-467. Springer, New York.

Weinberg ZG, Chen Y, Solomon R. 2008. The quality of commercial wheat silages in Israel. Journal of Dairy Science 92, 638-644.

Weinberg ZG, Muck RE. 1996. New trends and opportunities in the development and use of inoculants for silage. FEMS Microbiology Reviews 19, 53-68.

Weinberg ZG, Szakacs G, Ashbell G, Hen Y. 1999. The effect of Lactobacillus buchneri and L. plantarum, applied at ensiling, on the ensiling fermentation and aerobic stability of wheat and sorghum silages. Journal of Industrial Microbiology and Biotechnology 23, 218-222.

Wilkinson JM. 2005. Silage. Chapter 19. In: Wilkinson JM (ed.), Analysis and Clinical Assessment of Silage, pp. 198-208. Chalcombe Publications, Marlow, UK.

Zhang J, Kumai S. 2000. Effluent and aerobic stability of cellulase and LAB-treated silage of napier grass (Pennisetum purpureum schum). Asian-Australasian Journal of Animal Sciences 13, 1063-1067. 